\title{
The effect of carbonated beverage to the discoloration of polished and unpolished nanohybrid composite resin
}

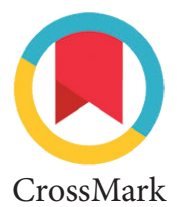

\author{
Hany Maghfiroh," Raditya Nugroho, Niken Probosari
}

\section{Abstract}

Objective: Nanohybrid resin composite is one of the restorative dental material that has a good aesthetic value and smooth surface. This study was proposed to determine the difference of discoloration of polished and unpolished nanohybrid resin composite after the immersion in carbonated beverage.

Material and Methods: An experimental laboratories research with the post-test only control group design was carried out. In the group of polished composite, polishing was done on only one side, while there was no treatment given to the unpolished composite group. There were 32 samples involved in this research divided into 4 groups which were immersed in carbonated beverages and artificial saliva for 7 days. The shredded material was replaced every 24 hours. The data was analyzed by the One-way
ANOVA and LSD (Least Significant Different) parametric statistical test. Results: There were significant differences between the unpolished composite resin that was soaked in carbonated beverages and the other groups $(p<0.05)$. mean value of the result of light intensity trial from composite group polished and soaked in carbonated drink (group D) suggested the lowest value of $398.25 \pm 4.773 \mathrm{mV}$. The mean value of the highest light intensity trial was in the polished composite group that was soaked in artificia saliva (groupA), $416.375 \pm 4.173 \mathrm{mV}$.

Conclusion: There are differences between the discoloration of polished and unpolished carbonated resin composite, after being soaked in beverages. The polished composite is more resistant to discoloration compared to the unpolished composite.
Faculty of Dentistry, Jember University, Jember, Indonesia

*Correspondence to: Hany Maghfiroh, Faculty of Dentistry, Jember University, Jember, Indonesia hannymaghfiroh@gmail.com

Received: 22 October 2015 Revised: 25 April 2016 Accepted: 26 April 2016 Available Online: 30 April 2016

Keywords: Carbonated beverage, Discoloration, Nanohybrid, Polished, Resin composite

Cite This Article: Maghfiroh H, Nugroho R, Probosari N. 2016. The effect of carbonated beverage to the discoloration of polished and unpolished nanohybrid composite resin. Journal of Dentomaxillofacial Science 1(1): 16-19. D0l:10.15562/jdmfs.v1i1.18

\section{Introduction}

Composite resin is a group of two or more different elaborated materials which has excellent quality. ${ }^{1}$ The composite resin is usually used because it has good aesthetic value. ${ }^{2}$ According to an overview presented by Tyas $^{3}$ the frequency of composite appliance is two time higher than amalgam and nearly four times higher than glass ionomer use. ${ }^{3}$ Based on the filling of the particle size, a composite is divided into macrofil or a conventional composite, little particle, hybride and microfil. ${ }^{1}$ The composite is continuously developing because it has more advantages than other restoring materials. There has been a recent progress of composite resin in nano technology and nano-composite. ${ }^{4,5}$ One of them is nanohybrid composite resin.

Nanohybrid resin is composite resin having filled materials in nanometer and micrometer. ${ }^{6,7}$ The composite has begun to be introduced since the beginning 2000s. ${ }^{4}$ Nano-composite is considered as the best composite because it has good mechanical endurance, has an easily produced soft surface, furrowing when it is being little polimerization, and it's ability to withstand in mouth cavity. ${ }^{8}$ The smaller the filling of the particle size, the more up-gradable the mechanical appearance of resin is. ${ }^{9}$
Nanohybrid composite has flexural strength of $130 \mathrm{MPa}$, compressive strength of $267 \mathrm{MPa}$ and diametral tensile strength of $81 \mathrm{Mpa} .^{7}$ Those wonderful intensities make the composite resin applicable for all the class of tooth caries.

The composite resin is an aesthetic restoring material, so the color will be a required problem to be observed. Still, composite resin can absorb fluid so it will be easy to change its color. ${ }^{2}$ A color change of composite is influenced by intrinsic and extrinsic factors. The intrinsic factors consist of resin matrix, kind of filling and interface changing between matrix and the filling agent including monomer which was not being polymerized perfectly. ${ }^{10,11}$ While, extrinsic factors come from around the environment such as food and drink and plaque as well. ${ }^{2,10}$ One type of drink which can influence the color of composite resin is carbonated drink. Some research has proved these findings such as the research by Effendi et al. ${ }^{12}$ showing that color changing significantly occurs in the composite immersedin carbonated drink. ${ }^{12}$ Another research performedby Ibrahim et al. ${ }^{2}$ proves that there is an absorption of stain material like wine, coffee, tea and soda sothe color of composite resin changes. ${ }^{2}$ 
Carbonated drink has $\mathrm{pH}$ about 2.5-3. It can cause erosion in restoration material. ${ }^{10}$ Moreover, drink having low $\mathrm{pH}$ contains much more ion $\mathrm{H}^{+} .{ }^{13}$ Many $\mathrm{H}^{+}$ions will affect chemical bond of composite polymer chain. If this condition continuously occurs, the composite will degrade the matrix and cause weathering. The crudeness on the surface caused by matrix degradation makes plaquing easy to patch. In addition, micro slot make the color of substance enter easily and the color of composite changes.

Nano-composite resin has so little filling particle, that is why the surface obtained tends to be softer than the others composite. Beside that, a good polishing procedure will make a composite to have soft and glittering surface.

Regarding to these backgrounds, it is required to conduct a research on the influence of the nanohybrid composite change of polished and unpolished resin.

\section{Material and Methods}

This research is a type of "experimental laboratories" design with the posttest only control group performed from March to April 2015 at Dental Hospital, Department of Conservative, Jember University, Microbiology Laboratory, Faculty of Dentistry. Optical Laboratory laser application was done at Department of Physics, Faculty of Science and Technology, Airlangga University.

Thirty two samples consist of four groups: group $\mathrm{A}$ is the group of composite resin which was polished and soaked in artificial saliva, group B is the group of composite resin which was polished and soaked in carbonated drink, group $C$ is the group of resin which was not polished and soaked in artificial saliva and finally group D in which the composite was neither polished nor soaked in carbonated drink.

Table 1 The result of light intensity trial (milivolt) for polished and unpolished nanohybrid composite in artificial saliva

\begin{tabular}{lcccc}
\hline Sample & A & B & C & D \\
\hline 1 & 413 & 416 & 433 & 390 \\
2 & 410 & 410 & 405 & 394 \\
3 & 413 & 416 & 410 & 396 \\
4 & 417 & 416 & 418 & 392 \\
5 & 421 & 411 & 419 & 384 \\
6 & 416 & 421 & 414 & 388 \\
7 & 422 & 413 & 417 & 388 \\
8 & 420 & 418 & 421 & 382 \\
Mean & 416.375 & 416.125 & 416.125 & 398.250 \\
\hline
\end{tabular}

This research began in sample production in the dark room to avoid premature polymerization. Sample imprints were made from insulin syringe in $5 \mathrm{~mm}$ diameter cut until it's thickness reached $2 \mathrm{~mm}$. Then, fixation was performed in a given source of yellow disk celluloid strip on the base part. Nanohybrid composite resin (Tetric $\mathrm{N}$-Ceram, Ivoclar Vivadent, A3) weighing as much as $0.15 \mathrm{~g}$ was then placed into an imprint with plastic filling instrument. It was covered by a celluloid strip and yellow disk, then a load of $1 \mathrm{~kg}$ for 5 minutes was applied so that the composite resin was more intense. Afterwards, composite resin was radiated by LED curing unit for 30 seconds (adapted to factory rules) to a tip sticking in celluloid strip and vertical applicable to sample surface. The last step of making the sample was polishing one side of polished resin composite group.

The next step was sample inundation. Sample was grouped and placed into the glass and labeled. All of the samples were soaked in artificial saliva for 24 hours so that the condition was like in a mouth cavity. Inundation was continued by using artificial saliva and carbonated drink on each group for 7 days, soaked solution was changed once every 24 hours. Then, it was placed into incubator $37 \pm$ $1^{\circ} \mathrm{C}$. Finally, all of them were washed by streaming water and dried using tissue.

A testing of light intensity used spectrophotometer consisted of $\mathrm{He}-\mathrm{Ne}$ laser, photo detector of type OPT 101 and digital multimeter. The laser light of $\mathrm{He}-\mathrm{Ne}$, the sample and the OPT 101 type photodetector type were placed in one direct line. ${ }^{10}$ The photo detector was connected to digital multimeter using fiber optic. It changed the light intensity values turned out tension so that digital multimeter appeared. This trial was performed by placing sample to its respective place in front of the transmitting point of laser apparatus and beamed by laser light of $\mathrm{He}-\mathrm{Ne}$ until the digital multimeter values appeared constant. The higher the values, the brighter the samples, such on the other hand.

\section{Results}

Based on the research performed, the result of sample light intensity has been obtained table 1 .

According to the table 1 and 2, it is indicated that mean value of the result of light intensity trial from composite group polished and soaked in carbonated drink (group D) suggested the lowest value of $398.25 \pm 4.773 \mathrm{mV}$. The mean value of the highest light intensity trial was in the polished composite group that was soaked in artificial saliva (group A), $416.375 \pm 4.173 \mathrm{mV}$. The estimated 
Table 2 Mean value of light intensity trial (milivolt) for polished and unpolished nanohybrid composites in artificial saliva and carbonated drink.

\begin{tabular}{lccc}
\hline Group & N & Mean $(\mathbf{m V})$ & SD \\
\hline A & 8 & 416.375 & 4.173 \\
B & 8 & 416.125 & 4.341 \\
C & 8 & 416.125 & 8.493 \\
D & 8 & 398.250 & 4.773 \\
\hline
\end{tabular}

A: polished composite in artificial saliva

B: polished composite in carbonated drink

C: unpolished composite in artificial saliva

D: unpolished composite in carbonated drink

SD: Standar deviation

Table 3 The test results of light intensity (millivolts) of polished and unpolished nanohybrid composites soaked in artificial saliva and carbonated drinks

\begin{tabular}{lcccc}
\hline Group & A & B & C & D \\
\hline A & & $0.000^{*}$ & 0.929 & 1.000 \\
B & $0.000^{*}$ & & $0.000^{*}$ & $0.000^{*}$ \\
C & 0.929 & $0.000^{*}$ & & 0.929 \\
D & 1.000 & $0.000^{*}$ & 0.929 & \\
\hline
\end{tabular}

Test LSD, $p<0,05,{ }^{*}$ shows significant value

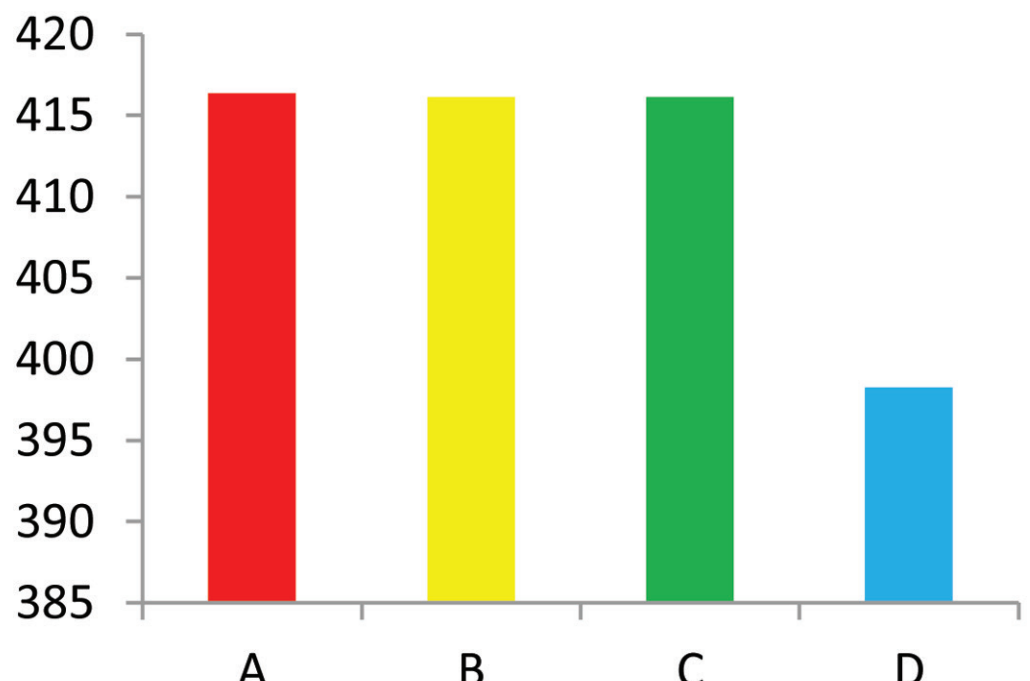

Figure 1 The mean value of light intensity trial diagram (milivolt) of polished and unpolished nanohybrid composite soaked in artificial saliva and carbonated drink

mean value of the light intensity of polished and unpolished nanohybrid composites indicated in a shaft diagram in figure 1.

The data had been tabulated and the normality was examined using the Shapiro-Wilk. The results obtained in each group were $0.706,0.777,0.638$ and 0.909 ( $p>0.05)$. It can be seen that the data were normally distributed. Homogeneity of the data with Levene test showed a significance of $\mathrm{p}=0.180$ ( $p>0.05)$, which could be categorized as homoge- neous. Because the data were normally distributed and homogeneous then continued by one-way Anova to determine the difference in color change on polished and unpolished nanohybrid resin composite soaked in artificial saliva and carbonated beverages $(p=0.000$ : $p<0.05)$ means that there is a difference in the treatment group. The group that has the important distinction, known to test the least significant difference (LSD) as shown in table 3 .

\section{Discussion}

A composite resin is restorative material with good aesthetical value and survivability that can last up to 10 years. However, the composite has a disadvantage since it can absorb liquid and dye. Discoloration of the composite resin is influenced by intrinsic and extrinsic factors ${ }^{2,10}$ intrinsic factors have an important role in color changes. Materials that are less good will cause the usage not optimal. The size of the filler material composite has a significant effect on color. ${ }^{14}$ The smaller the size of the filler material, the better the color's durability. In addition, the matrix resin used in dentistry is hydrophilic which makes the resin easy to change color. If the composites are sorted by their hydrophilic properties, we can obtain the following order TEGDMA-Bis-GMAUDMA-HEMA. ${ }^{10}$ When the matrix absorbs water, hygroscopic expansion will occur in the composite resin so that the matrix becomes less stable and the composite resin's density decreases.

Extrinsic factors affect discoloration of resin composites, one of them is a carbonated drink. Carbonated drinks have a $\mathrm{pH}$ of 3.29. Beverages with a low $\mathrm{pH}$ (3-6) can cause damage to the surface of the resin section. ${ }^{15}$ According to Valinoti et al. ${ }^{13} \mathrm{pH}$ is a reliable indicator to determine the initial concentration of the content of $\mathrm{H}^{+}$ion, ${ }^{13}$ the more acidic the solution, the higher the $\mathrm{H}^{+}$ ions contained in it. Acidity of carbonated drinks is caused by the reaction between water $\left(\mathrm{H}_{2} \mathrm{O}\right)$ and carbon dioxide $\left(\mathrm{CO}_{2}\right)$ which produces carbonic acid $\left(\mathrm{H}_{2} \mathrm{CO}_{3}\right)$. Carbonic acid will quickly dissociate to form protons and bicarbonate ions. ${ }^{16}$

Free $\mathrm{H}^{+}$ions will react with double bond carbon $(C=)$ in the polymer chain of the matrix resin composites that results in the termination of the polymer chain. It causes degradation in the matrix resin composite that makes the filler particles on the edge to easily dislodge. The release of filler material causes many small gaps in the composite, so that the resin becomes less dense which makes composite color darker. In the carbonated beverage products, Food and Drug Association declared that adding carbon is allow to only a permitted amount but there is no limit on how much it can be added 
to a beverage. Carbon in the carbonated beverage is also made of composite resin that changes its color. ${ }^{17}$ Free active carbon will break the polymer resin sothat it changes color. In addition, carbon can bindminerals contained in saliva so that precipitationoccurs. If it continuously occurs, it will form tartar.

Sweetener contained in carbonated drinks is quite a lot. This is due to the proportion of the sweetener in carbonated drinks which is around $10 \%$ of its volume. ${ }^{18}$ The amount of sweetener ingredients are expected to affect the growth of bacteria. The sweetener trapped in microcracks in the composite resin encourages the growth of bacteria. Hidden bacterial growth will be hard to control. If the accumulation of bacteria grows more, then the resin composite will be susceptible to discoloration. ${ }^{12}$

The existing differences are caused by the surface roughness of the sample. Composite surface is not polished and is more harsh than polished resin composite so the filler particles on the surface will be more easily separated due to the acidic conditions of carbonated beverages. It showed that the unpolished composite resin was more prone to discoloration than the polished composite. Nanohibrida composites containing nano-sized filler particles and particle size of the composite besar. ${ }^{7}$ If not polished, large-sized particles $(0.6 \mathrm{~m})$ tend to be easily detached and discolored.

Other studies related to the effect of the polishing procedure to discoloration of resin composites also mentioned that the polishing procedure can reduce the tendency to stain the composite. ${ }^{19}$ But it is also noteworthy because the procedure is less good. Polishing can cause composite surface becomes more rugged and will ease the accumulation of plaque, gingival irritation, as well as caries. ${ }^{20}$ Good polishing procedure will produce a surface that is smooth and shiny, extending the duration of use of composite and improving the aesthetic value. ${ }^{20}$ Finishing with a circular direction is better than the one direction because friction between the tool and the polished surface of the resin will be much smoother.

\section{Conclusion}

From these results, it is concluded that there are differences between the discoloration of polished and unpolished carbonated resin composite, after being soaked in beverages. The polished composite is more resistant to discoloration compared to the unpolished composite. It is suggested that the research may be expanded further in order to observe composite resin surface porosity in the polished and unpolished composites.

\section{Conflict of Interest}

The authors report no conflict of interest.

\section{References}

1. Anusavice KJ. Buku Ajar: Ilmu Bahan Kedokteran Gigi. Jakarta: EGC; 2003. p. 227-243.

2. Ibrahim MAM, Bakar WZW, Husein A. A comparison of staining resistant of two composite resins. Archives of Orofacial Sci 2009;1: 13-16.

3. Tyas MJ. Placement and replacement of restoration by selected practitioners. Australian Dent J 2005: 81-89.

4. Ferracane JL. Resin composite-state of the art. Dent Mater J 2010: 1-10.

5. Suzuki, Kyoizumi, Finger, et al. Resistance of nanofill and nanohybrid resin composites to toothbrush abrasion with calcium carbonate slurry. Dent Mater J 2009;28: 708-716.

6. Powers JM, Sakaguchi RL. Craig's restorative dental materials. 13th Ed. Philadelphia: Elsevier; 2006. p. 161191.

7. Fischer K, Lendenmann U. Scientific documentation tetric $\mathrm{N}$-Collection. Tidak diterbitkan. Schaan: Ivoclar Vivadent AG; 2010. p. 1-21.

8. Sideridou ID, Karabela MM, Vouvoudi E. Pyisical properties of current dental nanohybrid and nanofill light-cured resin composites. Greece: Elsevier; 2011. p. 598-607.

9. Mozartha M, Ellyza H, Andi S. Pemilihan Resin Komposit dan fiber untuk meningkatkan kekuatan fleksural fiber Reinforced Composite (FRC). J PDGI 2010;59: 29-34.

10. Dewi SK, Yuliati A, Munadziroh E. Evaluasi perubahan warna resin komposit hybrid setelah direndam obat kumur. Jurnal PDGI 2012;61: 5-9.

11. Wongkhantee, Patanapiradej, Maneenut, et al. Effect of acidic food and drinks on surface hardness of enamel, dentine, and tooth-colored filling materials. J Dent 2006;34: 214-220

12. Effendi MC, Nugraeni Y, Pratiwi RW. Pengaruh lama perendaman terhadap perubahan warna Resin Komposit Nanohibrida akibat konsumsi minuman soda aneka warna dan rasa 2013: 1-8.

13. Valinoti N, Silva, Mia. Surface degradation of composite resins by acidic medicines and ph-cycling. J Appl Oral Sci 2008;16: 257-265.

14. Abdel-Mohsen, El-Enin, Fahmy, et al. Evaluation of the effect of filler size loading, storage condition (Wet \& Dry) and storage time, on color change of light cured composites. Cairo Dent J 2009;25: 255:262.

15. Borges, Costa, Saavedra, et al. Color stability of composites: effect of immersion media. Acta Odontal 2011;24: 193199.

16. Ngili Y. Biokimia: Struktur dan fungsi biomolekul. 1st Ed. Yogyakarta: Graha ilmu; 2009. p. 262.

17. Zajkani, Tabrizi, Ghasemi, et al. Effect of staining solutions and repolishing on composite resin color change. J Islamic Dent Assc Iran (JIDAI) 2013;25: 84-90.

18. Coca Cola Company. 125 years what is coca cola? A briefing on our ingredients. Leaflet. Tidak diterbitkan. 2011. p. 1-17.

19. Barakah HM. Effect of surface polishing systems on color stability and surface roughness of nano-composite resin materials. Saudi Arabia:Kig Saud Univesity. 2010. p. 4-31.

20. LeSage, Brian. Finishing and polishing criteria for minimally invasive composite restorations. Cosmetic dentistry. The Academy of General Dentistry 2011: 422-428.

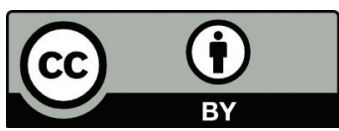

This work is licensed under a Creative Commons Attribution 